\title{
Audible Pasts: History, Sound and Human Experience in Southeast Asia ${ }^{1}$
}

\author{
BARBARA WATSON ANDAYA \\ Asian Studies Program, University of Hawai'i, 1890 East West Road, \\ Honolulu, Hawai'i 96822, USA \\ bandaya@hawaii.edu
}

Published online: 20 December 2018

To cite this article: Andaya, B.W. 2018. Audible pasts: History, sound and human experience in Southeast Asia. KEMANUSIAAN the Asian Journal of Humanities 25(Supp. 1): 1-19, https://doi.org/10.21315/kajh2018.25.s1.1

To link to this article: https://doi.org/10.21315/kajh2018.25.s1.1

\begin{abstract}
Although historians of traditional Southeast Asian cultures rely primarily on written sources, the societies they study were intensely oral and aural. Research on sound in Southeast Asia has focused on music and musicology, but historians are now considering the wide variety of noises to which people were exposed, and how the interpretations and understanding of these sounds shaped human experience. This article uses an 1899 court case in Singapore concerning a noisy neighbour as a departure point to consider some of the ways in which "noise" was heard in traditional Southeast Asian societies. Focusing on Singapore, it shows that European attitudes influenced the attitudes of the colonial administration towards loud noise, especially in the streets. By the late 19th century, the view that sleep was necessary for good health, and that noise interfered with sleep, was well established. The changing soundscape of Singapore in the early 20th century led to increasing middle class demands for government action to limit urban noise, although these were largely ineffective. The regulations and public campaigns introduced over the last 60 years still face the problem of intrusive noise, both in the public and private domain. The richness of the Singapore material, only some of which has been consulted for this paper, suggests that the Southeast Asian region has the potential to make a significant contribution to the field of sensory history.
\end{abstract}

Keywords and phrases: ethnicity, nervous anxiety, noise abatement, sensory history, Singapore

\section{Introduction}

In April 1899, a Singapore paper reported a court case involving a certain Mr. Zuzarte and Mrs. Rosa Sternberg. Mr. Zuzarte, whose name indicates he was of Portuguese descent, had been living in \#174 Middle Road for around 32 years. 
The adjoining terrace house, \#173, was rented by Mrs. Sternberg, who had originally opened an ice-cream and confectionary shop. However, this had not been profitable, and the previous year she had therefore started a bakery business. The baking began late at night and continued until early morning. Mr. Zuzarte brought his case to court because, he alleged, the battering, jarring, thumping and scraping noises caused by the beating of dough and the slamming of oven doors was so loud that he could not sleep. In sum, he argued that Mrs. Sternberg was making so much noise that it not only lowered the value of his property but was a fundamental impediment to the "quiet and peaceful" enjoyment of his home. Two supporters, brought in to testify on Mr. Zuzarte's behalf, said they too were unable to sleep and that the noise was "jarring" on the nerves (Straits Telegraph and Daily Advertiser 22 April 1899, 3).

In her defence, Mrs. Sternberg claimed that the noise from her bakery was "trifling and was not sufficient to wake a sleeping child". She kneaded her dough in a trough, not on a table, and used a knife to slip the rolls into the oven. Her neighbour on the other side, a Chinese man, said that he had lived there for six years and he was had not bothered by noise when the bakery began operating. However, the defence lawyer's argument that Mr. Zuzarte had exaggerated the affair, that reaction to noise is relative and that "the ticking of a clock would keep many people awake, whereas the five o' clock gun fired at Fort Canning, which is enough to wake the dead from their grave, does not at all disturb the soldiers" failed to sway the chief justice (Straits Telegraph and Daily Advertiser 22 April 1899, 3). Two days later he granted an injunction and awarded costs in favour of the plaintiff (Straits Telegraph and Daily Advertiser 25 April 1899, 3).

This scenario, not unfamiliar to modern apartment-dwellers, raises four issues that have provided a basis for this paper. In the first place, it is a reminder that the growing field of sensory history can be a useful way of thinking about the past, especially in non-Western societies. In the second place, this ruling occurred against a colonial background in which European suspicion of public noise was heightened by ethnic and class divisions. Third, the verdict in Zuzarte vs. Sternberg reflects a growing Western view that sleep was necessary to prevent nervous anxiety and that the law should intervene to protect individuals and the public from unacceptable noise that interfered with rest. Finally, the influence of the noise abatement movement that garnered so much international support in the first decades of the 20th century was also evident in Singapore. The legal ruling in the case of Zuzarte vs. Sternberg can thus be approached as an example of attitudes that anticipated the anti-noise regulations now embedded in Singapore's management of urban life. 


\section{Auditory History and the Southeast Asian Past}

In recent years the expanding field of auditory history has opened up new ways of thinking about the oral and aural environment that characterised much of the premodern world, including Southeast Asia. In urging us to "listen to the past", scholars working on aural history have stressed that the field itself is young and that "the history of listening, sound and noise outside of the United States and Europe begs for detailed attention and investigation" (Smith 2004, x). Yet, reconstructing the environment in which sound operated and the reactions to the acoustic context is not an easy task. Although a sneeze or a clap of thunder may "sound" more or less the same today as they did 200 or 300 years ago, we do not now hear them as our forebears did. Most societies no longer regard thunder as the voice of the heavens, nor see a sneeze as some kind of omen, since the development of scientific knowledge has changed the way we react to the auditory world. Cultural contexts, too, can radically alter the ways in which sounds are heard. Ancient Greeks, for instance, regarded a sneeze as a good omen, whereas in many other cultures it serves as a warning of uncertain but imminent danger; for the Ibans of Borneo it was thus a sign that no hunting should take place that day (Hastings, Selbie and Gray 1917, 398; Lumhultz 1991, 199). In other words, attitudes and beliefs about sounds can differ cross-culturally, and have changed over time. While many such beliefs have been lost, or can only be partially recovered, even those that have retained acoustic permanency no longer inform the lives of people in today's world, including most Southeast Asians. In the Malay Peninsular, men collecting gaharu wood in the jungle would once listen for what they described as a whispering in the trees, which would show that the tree contained the infected but fragrant heartwood, just as the sound of a cicada would indicate the presented of a camphor tree (Skeat 1967, 210). One would be hard pressed to find individuals with such acute hearing in contemporary Malaysia.

While listening to the quiet communication of jungle trees required particular sensitivity, no such requirement was attached to high volume levels, which could be heard by an entire community. Most of the premodern world, including Europe, believed that loud noises could have a force of their own that could even be lifethreatening, especially when they occurred unexpectedly. As various historians have shown, a conviction that the booming sound of thunder represented the cosmic voice of an immensely powerful supernatural agency was widespread (Rath 2003, 11, 56). In Southeast Asian societies, the perception of thunder as supernatural speech alerting the community to the perpetration of some immoral act or some portending disaster has a long history, and has even been discerned in the distant origins of Austronesian and Oceanic languages (Blust 1981). In historical times, one of the earliest references comes from the Vietnamese dynastic chronicles, 
which record that an 11th-century king "would shake with fright at thunderclaps", but similar reactions have also been described by modern ethnologists (Nguyen 1995, 111; Schebesta 1929; Roseman 1991, 137, 146). Infants were thought to be particularly vulnerable to loud and sudden noises; in 1886 the Malay author of a letter to a Singapore newspaper said that one Chinese man he knew had lost three children because they had been so frightened by the firing of the Fort Canning gun (Roseman 1991, 27; Sempang 1886, 1). On the other hand, predictable sounds produced by humans, especially in community activities - laughter, cheering and shouting - were generally regarded positively, even when extremely loud.

The emergence of the new field of sensory history is an exciting development for historians of non-Western cultures because it encourages the researcher to approach sources with fresh questions that can often yield unexpected but illuminating responses. Although ethnomusicologists and anthropologists have drawn our attention to the significance of sound in contemporary Southeast Asia, the region's auditory past has only recently attracted attention from historians (Andaya 2011; McCallum 2017; Raja Iskandar 2018; McCallum, forthcoming). However, because their research has focused on the Malay world, we cannot know whether their findings resemble the response to sounds in mainland Southeast Asia or further afield in the island environment. We can only hope for more case studies that will provide the basis for comparative overviews and thus expand our understanding of the region's auditory past.

\section{Ethnicity and the Regulation of Noise in Colonial Singapore}

In Southeast Asia, the spatial organisation of European-controlled towns that predated Singapore, notably Melaka, Batavia and Manila, followed well-established demographic patterns in which ethnic/religious communities clustered around sites of identification such as temples, mosques and churches. The soundscapes they produced carried specific meanings and targeted particular audiences - as funerals, as calls to prayer, as commemoration of past events, as religious processions and festivals - which typically involved the beating of drums and playing of gongs. The production of noise could equally be intended to restore community well-being in societies where loud noises were believed to drive away evil spirits or malevolent forces such as those that prevailed during eclipses (Marsden 1984, 157; Clifford 1898, 50; Skeat 1967, 12). Traditionally, subsections of Southeast Asian towns were free to develop their own acoustic environments and auditory identities, producing what R. Murray Schafer called "soundmarks", by which he means "a community sound which is unique or possesses qualities which make it specially regarded or noticed by people in that community" (Schafer 1977, 10). Because soundmarks were accepted as an expression of group identity, noise in public places was virtually never condemned, and in most cases was 
regarded positively. Communities generated loud noise from within their own auditory domains, and urban residents (and initially Europeans) accepted the noise of mosque calls, of Chinese funerals, of temple drumming, as part of the local soundscapes. Initially European authorities in these colonial towns appeared to be relatively tolerant of local soundings, in some cases even admitting their superiority; in 1687 the French envoy Simon de la Loubère thus acknowledged that Thai drums were "better than ours" (La Loubère 1969, 68-69).

By the early 18th century, however, we can discern a growing European distaste for human-produced sounds that were alien to their sense of what was aurally appealing or appropriate. During a visit to Banjarmasin in Borneo, for example, the country trader Daniel Beeckman talked about the "jangling" of brass gongs to celebrate a Muslim wedding "which jargon I can compare to nothing more like ... the noise of a copper-smith's shop, or even the thumping and jingling of chains by the mad-folks in Bedlam" (Beeckman 1718, 83). In Britain, the idea that individuals responsible for untoward noise were "vulgar" was widely accepted among middle and upper classes. Underpinning this idea, however, was the belief that the noise produced by unruly crowds was potentially dangerous. English monastic chroniclers had even referred to the peasant uprising of 1381 as "The Noise" and throughout the early modern period popular politics was associated with loud, clamorous and possibly threatening noise (Wood 2007, 114-116). Europeans in the new colonial cities of Southeast Asia similarly assumed that loud crowd noises could foreshadow the outbreak of violence. In 1710, for instance, a group of Indian Muslims were arrested in Dutch Melaka during the commemoration of Muharram because the noise they generated convinced the authorities that "the Moors" were about to mount an insurrection (Andaya 1983, 208). Indeed, in some case such convictions were justified. According to Dutch reports, it was "a terrible noise of drums, trumpets, basons, and hideous shouts" that signalled the beginning of the Chinese uprising in Java in 1740 ("The Insurrection at Batavia" 1741, 299).

At the same time, the 18 th century saw the emergence of other attitudes towards loud and uncontrolled sound. Enlightenment intellectuals stressed the distraction street noise posed to the scholarly or artistic mind, nicely captured by William Hogarth in his 1741 painting, "The Enraged Musician" (Phillips 2016, 15; see Figure 1). Yet though London was considered the noisiest city in Europe, the British judicial system had not yet formulated specific laws to deal with excessive noise in public places and the notion that city authorities should take official action to deal with this issue was novel (Goldsmith 2012, 58-61). Accordingly, when the English East India Company took possession of Singapore in 1819, there were no clear precedents for dealing with unfamiliar and "unwanted" noise, a matter that very quickly became a topic of debate because of the town's demographic composition. 


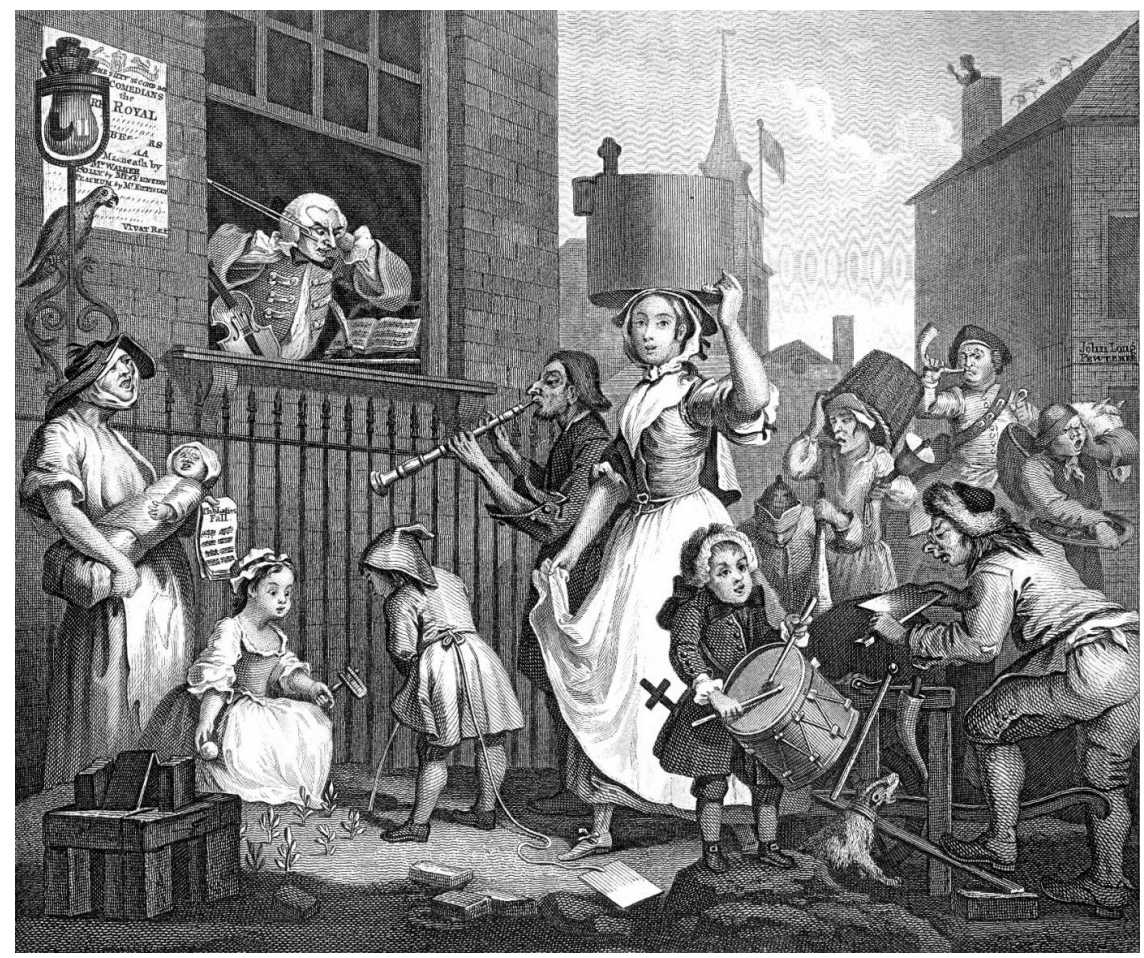

Figure 1. "The Enraged Musician” by Hogarth

Source: https://en.wikipedia.org/wiki/The_Enraged_Musician\#/media/ File:Enraged_musician.jpg (accessed 14 October 2018)

Singapore's first census in January 1824 recorded a population of 10,683 that comprised 74 Europeans; 16 Armenians; 15 Arabs; 4,580 Malays; 3,317 Chinese; 756 Indians and 1,925 Bugis (Buckley 1965, 154). These figures are open to some question, but by 1871, when the first reliable census was taken, the Chinese numbered 54,572, around $57 \%$ of the entire population (Yeoh 2003, 317). Europeans were thus vastly outnumbered by Asians who "were used to making sound in the open air and to the type of busy soundscape this produces. Moreover, they valued and deliberately created such soundscapes" (McCallum 2017, 318). In Malay texts, for instance, the phrases sangat ramai (extremely busy and noisy) and gegak gempita siang dan malam tiada berhenti (thunderous noise never stopping day and night) is associated with lively gatherings that reflect general well-being and implicitly, good governance. The Chinese who migrated to Southeast Asia brought a similar concept, encapsulated in the Mandarin term renao and the Hokkien lauziat, meaning "hot and noisy" but also "lively and bustling" (Andaya 2011; McCallum 2017, 2019). The same attitudes are found among traders and 
labourers from South Asia, especially in regard to religious celebrations, since worship without noise was not considered worship at all (Roberts 1994, 26). Like the Malay ramai, the Tamil term kalakalappu can be roughly translated as lively or exuberant, and is commonly used to describe both the sound and sight of crowded places, such as festive grounds, bazaars and temples. ${ }^{2}$

During the 19th century attempts by the Singapore government to regulate urban noise in public places were deeply implicated with the cultural and racial stereotypes that infused colonial society. As Jenny McCallum (2017) has shown, for much of this period differences in attitudes regarding the degree to which "noise" was acceptable focused on the street processions mounted by the different ethnic communities. Because street noise, including the beating of drums and cymbals, was frequently associated with religious festivals, European demands for restrictions that better dealt with Asian "noisiness" were to some degree frustrated by the extension of Penang's 1807 "Charter of Justice" to include Malacca and Singapore. Coming into force in 1827, the Second Charter of Justice reiterated that any regulations should follow English common law, while giving "due attention to the several Religions, Manners and Usages of the native Inhabitants" (Braddell 1915, 78). Notwithstanding these provisions, objections from European residents increased as the older patterns of ethnic settlement broke down and as the soundmarks of other communities penetrated into white enclaves. In 1823, Stamford Raffles himself had objected to the noise of Chinese fireworks, but they continued to incur European condemnation as a disturbance and a public nuisance (Buckley 1965, 505). The author of one letter to the Singapore Free Press, evidently aware of the provisions of the Charter of Justice, suggested a possible compromise, "If it does seem meet to show respect for the 'customs of the natives' they should be restricted to particular hours and places" (Buckley 1965, 313).

Despite considerable pressure, during the first two decades of Singapore's existence, the authorities did not move to prohibit processions. However, in 1837 debates over what should be considered "customary noise" reached a head when a Chinese Singapore family was given permission to hold a wedding procession on the condition that there should be no fireworks and no gongs. This ruling generated a series of petitions not only from Chinese but from European or Eurasian supporters, who contended that the noise of gongs and firecrackers was a basic element in religious ceremonies. A less tolerant view was expressed by Europeans who felt that processions should be banned altogether, for in the words of one correspondent: "The Native Festivals are of course numerous. If every class was to have its own way the town would be in a continual clamour by noisy and riotous processions" (Buckley 1965, 357). 
It is worth remembering, however, that such criticism was not limited to Europeans, for the attitudes of English-educated Asians, reflected in the correspondence of English-language newspapers, point to new tensions as ethnic communities compared the ways in which they had been treated by the authorities. Chinese complained that they were penalised by laws against fireworks, since they were permitted for other races during their celebrations. "Is it because we Chinese are not equal to the Klings or the Malays?" (Sinha 2011, 70). Malays, however, saw the situation differently. Writing in defence of the celebration of Muharram, a certain Awang bin Mohammad argued that it was "a universal custom for all nations to celebrate the anniversary of their festivals in their own fashion" and that "the Chinese make more noise than we do, and besides their feasts last much longer ... why should we be the only nation prevented from enjoying ourselves on our great day?" (Straits Times Weekly Issue 2 September 1886, 14). Yet in some contexts Singaporeans themselves closed ranks against outside criticism. In later years, when a Penang visitor (apparently a European) complained that he could not sleep in Singapore because of the noise of mosque calls and church bells, a Chinese woman responded by saying he should go and live near a cemetery; why, she asked, did he choose to live in the tropics if he wanted to sleep after $5 \mathrm{AM}$ ? (Lim 1934, 6).

\section{Noise, Sleep and Mental Health}

Tracked through letters and notifications in English-language newspapers, studies of Singapore's "sound history" in the 19th century have highlighted shifting attitudes to processions as authorities responded to changing political and social contexts (Sinha 2011, 62-81; McCallum 2017, 322-329). By the 1880s, however, it appears that more attention was being accorded to civil disputes, often between neighbours. The "thumping and scraping" to which Mr. Zuzarte objected had not taken place in a public place, and was not associated with a particular ethnic group. What is intriguing about Mr. Zuzarte's allegations was the idea that he could appeal to the law to protect his "private space" and its auditory boundaries. The noise made by Mrs. Sternberg had imposed an unwelcome and uncontrollable aural presence in what he regarded as his own domain - indeed, nearly 50 years later the United States Supreme Court would categorise such intrusion as "aural aggression" (Anzalone 2000, 134). The fact that the presiding judge, Justice T. de M.L. Braddell, was also Attorney General of the Straits Settlements, indicates that the ruling for a case that today might appear trivial was given serious attention.

Several possible reasons may account for this development. Certainly, among Europeans in Singapore there was still a lingering fear that gatherings of large, noisy and uncontrolled crowds could escalate into outbursts of anger directed 
towards colonial authorities. Yet despite the so-called Veranda Riots of 1888 , the participation of Asian citizens in Queen Victoria's jubilee celebrations the previous year and in memorials following her death in 1901 allayed doubts about the loyalty of Singapore subjects (Yeoh 2003, 250-253; McCallum 2017, 329). Meanwhile, Singapore was also feeling the influence of increasing global attention in regard to household noise and neighbourly relations. An impressive example of this trend was the Netherlands decision to make disturbance of a neighbour's sleep at night an actual crime (Bijsterveld 2003). In much of Europe and North America, a growing middle class viewed their quiet homes and quiet neighbourhoods as a contrast to the random and unrestrained noise associated with lower socioeconomic groups. In their opinion, a society that restrained undue noise was an ordered society. The well-known social commentator, the American E.L. Godkin (1831-1902) lent force to this argument, contending that "the progress of a race in civilization may be marked by a steady reduction in the volume of sound which is produces. The more culture of all kinds it acquires, the less noise it produces". Noisy street celebrations like those that occurred on the 4th of July were thus seen by many as "hideously vulgar and utterly uncivilized" (Smilor 1977, 27). Such views were particularly pertinent in Singapore, where the British believed that part of their obligations as a colonial power was to foster in their subject populations the moral and ethical values of British culture. Becoming "civilised" was a quiet affair, and its counterpart, noise, was primitive and potentially damaging to social order. For the British in Singapore and the Eurasians who emulated them a quiet home became a hallmark of identity, distinguishing from other ethnic groups who were regarded as inherently noisier.

At the turn of the 19th century, the concern with fostering a quiet society developed deeper and more personal ramifications because of the emphasis on the importance of uninterrupted sleep as a prerequisite for physical and mental health. These ideas, of course, did not develop overnight, but reflected evolving attitudes towards the organisation of the human day. In pre-industrial times sleep was often broken into shorter periods, alternated with times of activity, work and social interaction, but during the 18th century the idea that sleep should be seamless rather than segmented began to spread from propertied to working classes (Ekirch 2006, 301306). Two years before Singapore was established the Welsh socialist, Robert Owen (1771-1858), had even coined the slogan "Eight hours labour, Eight hours recreation, Eight hours rest" as a right for all workers.

In the ensuing years the conviction that eight hours uninterrupted sleep was not merely an entitlement, but essential for good health was supported by mounting medical evidence. In 1867, for example, a book by the well-known herbalist, O.P. Brown, stressed that the hours of darkness were intended for sleep and that daylight 
should be set aside for productive activity. Dozing during the day, it was contended, was not only debilitating, but a mark of lesser "napping" cultures (Steger and Brunt 2003, 67; Brown 1867, 249). Other publications by individuals with varying medical credentials similarly emphasised the connection between lack of sleep and various nervous disorders, now encapsulated in a new term, "neurasthenia". First used in the 1870s and subsequently popularised by the American neurologist, George M. Beard, neurasthenia was seen as a particularly masculine complaint. The symptoms were numerous, and diagnosis could cover a wide range of conditions, but one common feature was sleeplessness caused by "noises that are arhythmical, unmelodious, and therefore annoying, if not injurious" (Mansell 2017, 30-37). In the late 19th and early 20th centuries, it was widely believed that men in colonial settings were particularly vulnerable to neurasthenia because they were directly involved in environments where noise was constant (Kennedy 2017; Mansell 2014, 278-9). The British official Hugh Clifford himself accepted that Europeans could become more "nervous" in a tropical climate, and thus resemble Malays, who were generally were "extraordinary sensitive" to sudden noises (Clifford 1898, 196-198).

Published in 1896, G.T.W. Patrick and J.A. Gilbert's much-cited study of sleep deprivation was the first serious research using human subjects, providing clear evidence that lack of sleep impaired motor performance, weakened memory and impeded timely reactions. The European and North American public, however, was already convinced that because wakefulness was caused by the intrusion of noise, its removal could restore correct sleep patterns. If the absence or muting of noise was necessary for sleep, and sleep was necessary for good health, then the authorities had a responsibility to ensure that a suitable environment prevailed. In Britain and North America, magazines and newspapers were flooded with letters deploring the intrusion of noise into public spaces and calling for government intervention to control the "tumult" that involved barrel organs, Salvation Army drums, and even "the ceaseless tinkle of those instruments of torture attached to the harness of horses drawing tramway-cars" (Straits Times Overland Journal 4 August 1881). Opponents of the pealing of church bells were particularly outspoken and one commentary published in the medical journal, The Lancet, in 1881, was repeated in the Straits Times Overland Journal. According to The Lancet's correspondent, the pealing of church bells "constitutes a very serious annoyance" causing a loss of rest and general disquietude, "It is difficult to exaggerate the magnitude of the evil to which we draw attention" (Straits Times Overland Journal 4 August 1881, 2). From this perspective, unwelcome noise was an offence to the individual right to a quiet life; Mr. Zuzarte would have found many supporters in New York when he complained that his private space was being invaded. "How soon shall we learn", wrote one American in 1900, "that one has no more right to throw noises than they have to throw stones into a house?" (Smilor 1977, 25). 


\section{Public Pressure, Government Action and "Noise Abatement"}

The case of Zuzarte vs. Sternberg demonstrates a growing awareness of legal rights and the problem of "noisy neighbours", but at this very time other developments were turning public attention once more to the street. In 1896, the first automobile was imported into Singapore, and by the end of World War I there were more than 1800 motorized vehicles on local roads. By the 1930s, traffic noise was compounded by other technical innovations - radios, gramophones, loudspeakers - that made households noisier, especially since windows were usually left open. To this cacophony of new sounds was added the noise of machinery and construction work that accompanied the building of factories, rubber mills and other industrial developments. Vociferous objections to the honking of the car horn or "hooter", the blaring of music from microphones and radios, and the din of construction were simply added to continuing complaints about hawkers, firecrackers, mosque calls, Chinese opera and Tamil chanting. Demands for action reflected the growing anti-noise movement overseas, where lobbyists and activists increasingly demanded government intervention. In the words of an American physician and health advocate, "Sound, restful sleep in the presence of noise is impossible ... The public has to been quite too tolerant and long-suffering in this matter" (Kellogg 1915, 219).

The major problem, of course, was how to differentiate between sound and unacceptable noise, since it was acknowledged that individuals differed in their degree of tolerance. At this point there was no way of measuring when a sound became noise. As one Singapore correspondent noted:

We have at present no method of specifying the loudness or characteristics of a sound, unless it is a musical note. We can use words like 'crash', 'bang', 'tinkle', 'rattle', but these give only a vague indication of what the noise is like. (Singapore Free Press 8 April 1920, 5)

It was European judgments that determined when the barrier had passed, and they did this through comparing Singapore and other cities with their home environment. In 1924, for instance, a newly arrived Englishman compared the "terrible" Singapore traffic noise to the relative quietness of London (Straits Times 6 August 1924, 10).

By the late 1920s, however, new tools became available when the measurement of sound came into popular use. Advances were most evident in the United States. In 1929, acoustical engineers used a new measurement of sound called the decibel to assess the noise levels in Times Square (Figure 2). In the same year, the influential Scientific American established a concrete definition of "din". It is defined as "any 
noise made at times of the day or night when it is most likely to be disturbing; any noise that is loud, screeching, strident, or discordant, and any noise that is discontinuous and unrhythmic" (Smilor 1977, 34). In 1929, too, the American Public Health Association estimated that lack of sleep was a key element in 75 percent of cases of mental breakdown, and a commission in New York City concluded that "a state of emergency exists in New York City as a result of the increase in noise" (ibid.).

In Singapore and Malaya, the English language press followed these developments closely. The ability to measure the every-increasing cacophony of urban life and its effects on ordinary people simply increased demands for greater control. Public observation of two minutes silence during the annual commemoration of Armistice Day, though admittedly not "perfect", still registered the degree to which noise penetrated city life. It is surely no coincidence that references to "tropical neurasthenia" now recur more frequently (Straits Times 12 November 1924, 9; Singapore Free Press 16 June 1931, 7; Cody 2009, 91-94). As in London and New York, the city street emerged to become what Peter Bailey has termed "the front line" in the contest over noise and the perceived governmental task of persuading or enforcing the populace to reduce the level of noise (Bailey 1998, 194-211).

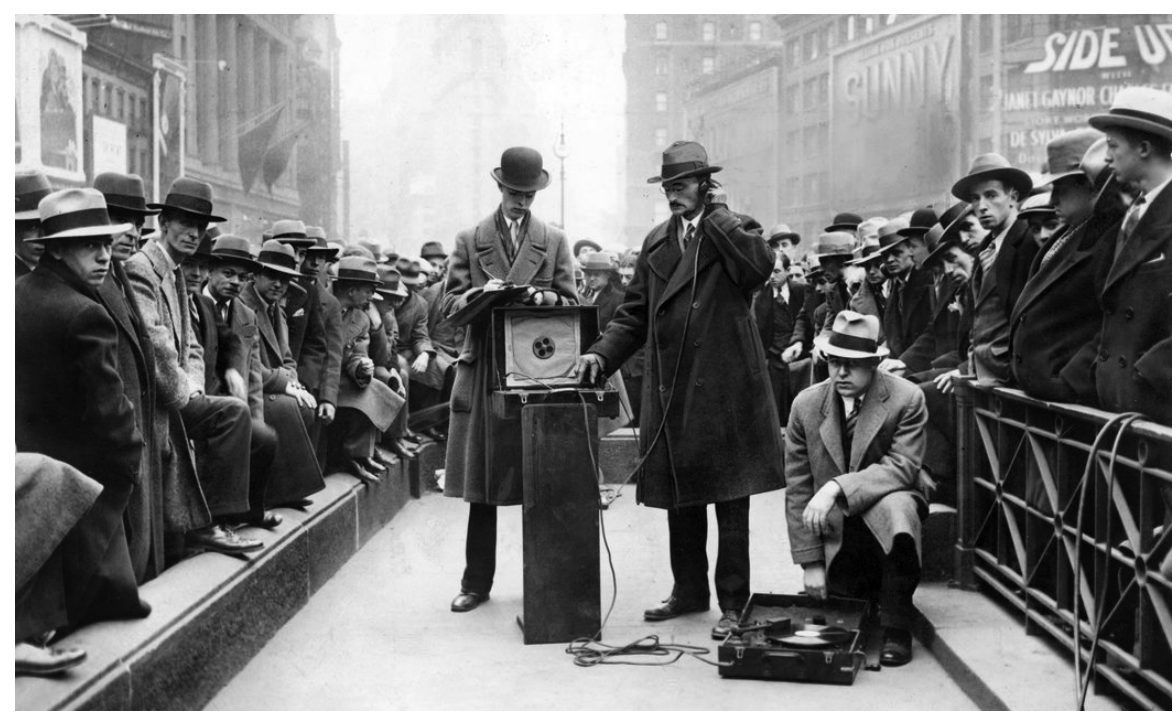

Figure 2. In 1929, acoustical engineers used a new measurement of sound called the decibel to assess noise levels in Times Square

Source: Times Wide World Photos. https://www.nytimes.com/2013/07/13/nyregion/manypleas-for-quiet-but-city-still-thunders.html (accessed 14 October 2018) 
European pressure for the Singapore government to address the "scourge of noise" was expressed in rising support for noise abatement programmes like those in America and Britain (Singapore Free Press 15 July 1931, 3). In this context, the British connection was significant. In the United States, support for the anti-noise movement waned after 1929 as public concerns were overwhelmed by the dire economic effects of the Depression. Public sympathy had been especially strong in New York, but even here the first anti-noise law was not passed until 1936 (Smilor $1972,447 ; 1977,35)$. In Britain, on the other hand, campaigns gained renewed strength with the formation of the Anti-Noise (subsequently Noise Abatement) League in 1933, headed by the king's personal physician, Lord Horder. His name appeared frequently in Singapore newspapers and he was, like many other men in medical circles, convinced that incessant urban noise could lead to neurasthenia. Yet despite a forceful public crusade that promised a national revival of "nervous energy" when silence was restored, politicians in Britain remained sceptical and the pace of legislative change was frustratingly slow (Mansell 2017, 49-59).

In Singapore it is also evident that attitudes towards noise abatement remained ambiguous. Notwithstanding age-old complaints about mosque calls, the world's first loudspeaker to sound the azan was installed in Singapore's Mesjid Sultan mosque, justified because "the noise of the modern city demand an accompanying increased in the power of the muezzin's voice" (Straits Times 29 December 1936, 11). Other commentators wondered when the regulations supporting noise abatement should give way to economic considerations, especially as Singapore was recovering from the Depression. In 1938, citing the views of Lord Horder, the Malaya Tribune argued that the entire question of noise control would have to be "tackled afresh" because of the rapid expansion of factories and industrial districts and their encroachment into residential area. On the other hand, the article reminded readers that Singapore had lost a General Motors assembly plant to Batavia because the proposed site, near the Singapore Swimming Club, was not approved (Malaya Tribune 4 August 1938, 11).

From 1939, complaints about noisy cafes, noisy neighbours and noisy street performances still surfaced in the English language press, but public anxiety was now taking a very different direction as war clouds loomed and as Japanese intentions became clearer. In April 1941, responding to a mood of growing apprehension, a letter to the Straits Times proposed the organisation of an islandwide function that would provide an outlet for "joyful noise", help relieve "pent up feelings" and even reinforce the war effort (Straits Times 3 April 1941, 8). While there is no indication that this suggestion was taken up, it is possible that the writer was implicitly referencing nostalgic memories of the enjoyable and clamorous noise that had once characterised Singapore streets. Just a few months later, 
however, warfare brought its own kind of terrible noise to Singapore, but after the surrender the slow path back to normalcy resurrected old complaints about the damaging effects of street noise. Indeed, one of the first appeals to the returning British administrators was that measures be taken to reduce the din of "non-stop loud-speaker music" from Indian restaurants on Serangoon Road, which added to the confusion caused by the "congested whirling vehicular and human traffic" (Straits Times 30 July 1946, 4).

The expectation that the "City Fathers" should do something to deal with "nerveracking noise" recalls not only Mr. Zuzarte's petition to the chief justice, but foreshadows modern policies that mark Singapore's auditory history. Although the definition of "intolerable noise" was still debated, the government of independent Singapore began to give serious attention to a noise abatement programme. Prime Minister Lee Kuan Yew's campaign in the 1970s signalled the acceptance of official responsibility for reducing noise in the interests of public health and enjoyment of life. The Ministry of the Environment has continued to refine regulations that measure acceptable decibel levels for industrial operations, construction and community activities, including "mosque calls, Chinese opera, funeral processions, church bells, Chinese and Indian temples, music during weddings, record shops and places of entertainment" (Lee 1999, 90).

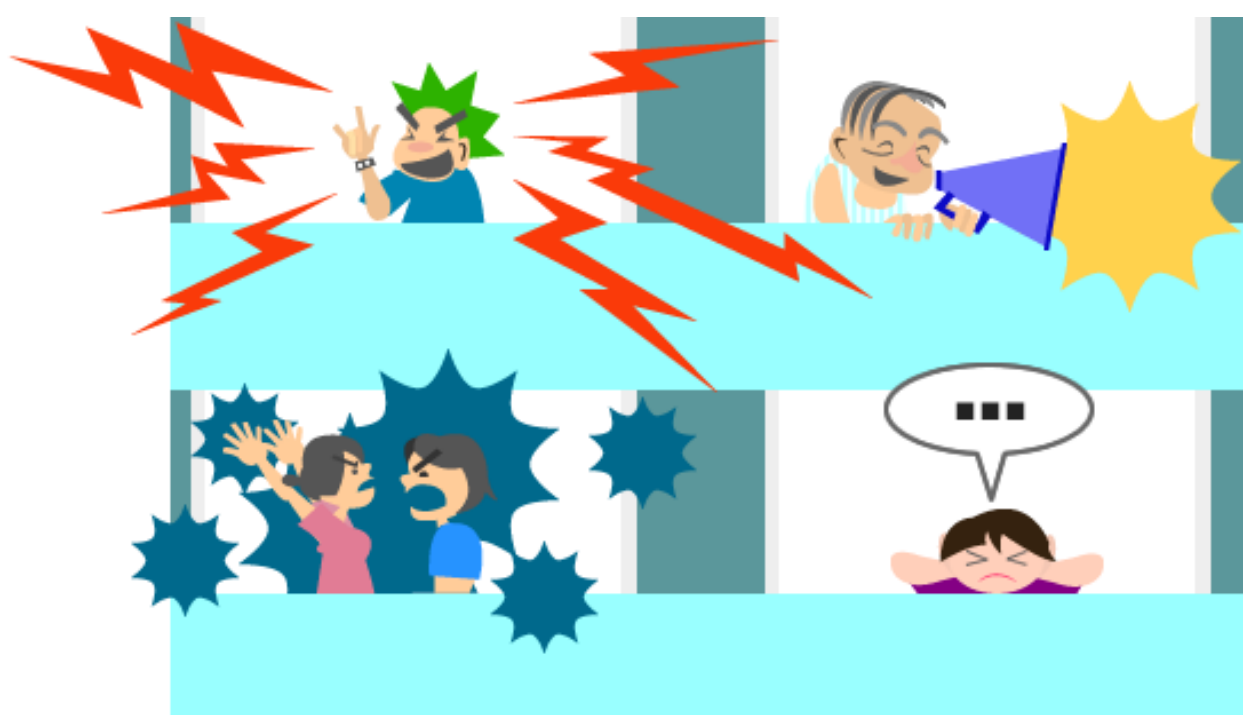

Figure 3. Anti-noise poster from Singapore's Ministry of the Environment and Water Resources

Source: https://www.mewr.gov.sg/topic/noise-pollution (accessed 13 October 2018) 
For the most part, the Singapore government has been largely successful in policing noise levels in the public domain, but conflicts between neighbours alleging unacceptable noise in densely populated housing estates continue to surface (Figure 3). In 2016, for example, 70 percent of the 79 cases reviewed by Singapore's Community Disputes Resolution Tribunals involved claims of "excessive noise" (Wan 2016). At the same time, however, tens of thousands of Singaporeans are now living next to busy roads, train tracks, construction sites and shopping malls and apartment walls are rarely thick enough to block out the noise (Ng 2017). Well over a hundred years ago the Chief Justice of Singapore accepted Mr. Zuzarte's argument that noise should not interfere with the "quiet and peaceful" enjoyment of his property. Today, though still acknowledged in principle, that ideal is far from reality.

\section{Conclusion}

This paper used a legal injunction in 1899 as a departure point to think about the ongoing history of sound in Singapore in relation to private and public spheres. From the very earliest years, it was evident that European attitudes towards noise, especially loud noises, differed considerably from those of the Asian populations who represented the overwhelming majority of Singapore residents. For the greater part of the 19th century public concern was focused on street noise, particularly that produced by processions. Even though disputes regarding household noise began to receive greater attention, the amplification of urban noise in the early 20th century became a major concern because it was thought to endanger mental and physical health. The emergence of an anti-noise movement in Britain and North America reverberated in Singapore, but government action in the interwar period had few noticeable effects. Despite the post-independence introduction of strict regulations regulating noise levels, and ongoing educational campaigns, "noise pollution" in Singapore has become a fact of life.

In recent years, a number of scholars have responded to the call for greater attention to the "sensory dimensions of history", and a succession of studies drawing from European and North American material have illuminated the ways in people in the past saw, smelled, tasted, touched and heard their world (Smith 2008, 379380 ). In the case of Singapore, a concern with the meanings of local soundscapes and their significance in a multicultural population can be traced thematically for well over 200 years. Singaporeans now live in a much noisier world than their forebears, even though authorities no longer beat drums, ring bells or fire cannon to summon citizens. The values attached to sound, especially loud sound, have also changed. Ethnic soundscapes are more muted and their auditory domain has contracted, but "noise" remains a topic of often heated debate. While this paper 
has tapped some of the English sources available, research on attitudes expressed in Malay and Chinese publications has yet to be examined. And as an addendum, the much-publicised controversy regarding migrant Chinese objections to the smell of Indian curry leads me to wonder whether the olfactory sense can generate its own "Singapore story" (Howes and Classen 2013, 88). I can only reiterate that as the study of the senses opens up in non-Western environments, Singapore's unique but neglected sensory history will surely have much to contribute to what is now a global conversation.

\section{Notes}

1. A much earlier version of this paper was originally presented at the Dr. Ben Batson lecture of 2012, sponsored by the History Department, National University of Singapore.

2. I am most grateful to Dr. Sureshkumar Muthukumaran for suggesting the Tamil term.

\section{References}

Andaya, B. 2011. Distant drums and thunderous cannon: Sounding authority in traditional Malay society. International Journal of Asia Pacific Studies 7(2): 19-35.

Andaya, B.W. 1983. Melaka under the Dutch, 1641-1796. In Melaka: The transformation of a Malay capital c. 1400-1980, eds. K.S. Sandhu and P. Wheatley, 195-241. Kuala Lumpur: Oxford in Asia.

Anzalone, C.A. (ed.). 2000. Encyclopedia of supreme court quotations. New York: M.E. Sharpe.

Bailey, P. 1998. Popular culture and performance in the Victorian city. Cambridge: Cambridge University Press.

Beeckman, D. 1718. A voyage to and from the island of Borneo, in the East-Indies. London: T. Warner.

Bijsterveld, K. 2003. "The City of Din": Decibels, noise, and neighbors in the Netherlands, 1910-1980. Osiris 18(1): 173-193. https://doi.org/10.1086/649383

Blust, R. 1981. Linguistic evidence for some early Austronesian taboos. American Anthropologist 83: 285-319. https://doi.org/10.1525/aa.1981.83.2.02a00020

Braddell, R.S.J. 1915. The law of the Straits Settlements: A commentary. Singapore: Kelly and Walsh.

Brown, O.P. 1867. The complete herbalist, or, the people their own physicians by the use of nature's remedies. London: Self-published.

Buckley, C.B. 1965. An anecdotal history of old times in Singapore. Singapore and Kuala Lumpur: University of Malaya Press. Reprint of 1902 edition.

Clifford, H. 1898. Studies in brown humanity, being scrawls and smudges in sepia, white, and yellow. London: G. Richards.

Cody, M.K. 2009. A paler shade of white. In Lost times and untold tales from the Malay world, eds. J.v.d. Putten and M.K. Cody, 52-96. Singapore: NUS Press. 
Ekirch, A.R. 2006. At day's close: Night in times past. New York and London: W.W. Norton.

Goldsmith, M. 2012. Discord. The story of noise. Oxford: Oxford University Press.

Hastings, J., Selbie, J.A. and Gray, L.H. 1917. Encyclopaedia of religion and ethics (vol. 9). Edinburgh: T and T Clark.

Howes, D. and Classen, C. 2013 Ways of sensing: Understanding the senses in society. London: Routledge. https://doi.org/10.4324/9781315856032

Kellogg, J.H. 1915. Neurasthenia; or nervous exhaustion. Battle Creek, MI: Good Health Company.

Kennedy, D. 2017. Minds in crisis. Medico-moral theories of disorder in the late colonial world. In Anxieties, fear and panic in colonial settings: Empires on the verge of a nervous breakdown, ed. H. Fischer-Tiné, 27-48. Cham, Switzerland: Springer.

La Loubère, S. de. 1969. A new historical relation of the kingdom of Siam; with an introduction by David K. Wyatt. Kuala Lumpur: Oxford University Press.

Lee, T.S. 1999. Technology and the production of Islamic space: The call to prayer in Singapore. Ethnomusicology 43(1, Winter): 86-100.

Lim. E. 1934. Letter to the Editor. Straits Times, 29 September.

Lumhultz, C. 1991. Through central Borneo: An account of two years travel in the land of head-hunters between the years 1913 and 1917. Singapore and New York: Oxford University Press. Reprint of 1920 edition.

Mansell, J.G. 2014. Neurasthenia, civilization, and the sounds of modern life. Narratives of nervous illness in the interwar campaign against noise. In Sounds of modern history: Auditory cultures in 19th-and 20th-century Europe, ed. D. Morat, 278-302. New York and Oxford: Berghahn.

2017. The age of noise in Britain: Hearing modernity. Urbana and Chicago: University of Illinois Press. https://doi.org/10.5406/illinois/9780252040672. 001.0001

Marsden, W. 1984. A history of Sumatra. London: Thomas Payne and Sons.

McCallum, J. 2017. Conflict and compromise over processional sound in 19th-century Singapore. Indonesia and the Malay World 45(133): 315-333. https://doi.org/10.10 80/13639811.2017.1340533

Forthcoming. Sound, space and social relations in nineteenth-century literary texts from the Riau Archipelago. In Performing the arts of Indonesia: Malay identity and politics in the music, dance and theatre of the Riau Islands, ed. M J. Kartomi. Copenhagen: NIAS Press.

Ng, J.S. 2017. Living with noise pollution: Serangoon, Bukit Timah and Clementi among the noisiest neighbourhoods in Singapore. Straits Times, 23 April. https://www. straitstimes.com/singapore/housing/sounds-awful-cant-sleep-cant-talk-because-ofnoise (accessed 19 August 2018).

Nguyen, C.T. 1995. Rethinking Vietnamese Buddhist history: Is the Thien Uyen Tap Anh a 'Transmission of the Lamp' text? In Essays into Vietnamese pasts, eds. K.W. Taylor and J.K. Whitmore, 81-114. Ithaca, NY: Cornell University Southeast Asia Program. 
Patrick G.T.W. and Gilbert, J.A. 1896. Studies from the psychological laboratory of the University of Iowa. On the effects of loss of sleep. Psychological Review 3(5): 469-483. https://doi.org/10.1037/h0075739

Phillips, N.M. 2016. Distraction: Problems of attention in eighteenth-century literature. Baltimore, MD: Johns Hopkins University Press.

Raja Iskandar bin Raja Halid. 2018. The nobat in early Malay literature: A look into the Hikayat Patani. Indonesia and the Malay World 46(135): 168-197. https://doi.org/ 10.1080/13639811.2018.1444963

Rath, R.C. 2003. How early America sounded. Ithaca and London: Cornell University Press.

Roberts, M. 1994. Exploring confrontation: Sri Lanka-politics, culture, history. Chur, Switzerland: Harwood Academic Publishers.

Roseman, M. 1991. Healing sounds from the Malaysian rainforest: Temiar music and medicine Berkeley: University of California Press.

Schafer, R.M. 1977. The tuning of the world. New York: Knopf.

Schebesta, P. 1929. Among the forest dwarfs of Malaya (Trans. by A. Chambers). London: Hutchinson \& Co.

Sempang, H. 1886. Letter to the Editor: The time gun. Straits Times Weekly Issue, 2 September.

Sinha, V. 2011. Religion-state encounters in Hindu domains: From the Straits Settlements to Singapore. London and New York: Springer. https://doi.org/10.1007/978-94007-0887-7

Skeat, W.W. 1967. Malay magic. New York: Dover. Reprint of 1900 edition.

Smilor, R.W. 1972. The New York City noise control code: Not with a bang but a whisper. Fordham Urban Law Journal 1(3): 446-466.

1977. Cacophony at 34th and 6th: The noise problem in America, 1900-1930. American Studies 18(1): 23-28.

Smith, M.M. 2004. Introduction: Onward to audible pasts. In Hearing history: A reader, ed. M.M. Smith, ix-xxii. Athens and London: University of Georgia Press.

2008. Still coming to 'our' senses: An introduction. The Journal of American History 95(2): 378-380. https://doi.org/10.2307/25095623

Steger, B. and Brunt, L. 2003. Night-time and sleep in Asia and the West: Exploring the dark side of life. London: Routledge.

Straits Telegraph and Daily Advertiser. 22 April 1899. Zuzarte vs. Mrs. Sternberg. http://eresources.nlb.gov.sg/newspapers/Digitised/Article/straitstelegraph189904221.2.12.4 (accessed 9 October 2018).

25 April 1899. Zuzarte vs. Mrs. Sternberg. http://eresources.nlb.gov.sg/ newspapers/Digitised/Article/straitstelegraph18990425-1.2.15 (accessed 9 October 2018).

Sweeney, A. (ed.). 2006. Karya lengkap Abdullah bin Abdul Kadir Munsyi jilid 3: Hikayat Abdullah. Jakarta: Kepustakaan Populer Gramedia and École française d'ExtrêmeOrient.

“The Insurrection at Batavia". 1741. In The Scots Magazine (vol. 3, pp. 299-301). Edinburgh: Sands, Brymer, Murray and Cochran. 
Wan, W. 2016. Of noisy neighbours and silent nights. The Straits Times, 12 December. https:/www.straitstimes.com/opinion/of-noisy-neighbours-and-silent-nights (accessed 29 July 2018).

Wood, A. 2007. The 1549 rebellions and the making of early modern England. Cambridge: Cambridge University Press. https://doi.org/10.1017/CBO9780511496141

Yeoh, B. 2003. Contesting space in colonial Singapore: Power relations and the urban built environment. Singapore: NUS Press. https://doi.org/10.2307/j.ctv1ntj2v

Yi, S.B. 2016. Almost 70\% of neighbour disputes heard by tribunals involve 'excessive noise': State Courts. Straits Times, 23 September. https://www.straitstimes.com/ singapore/courts-crime/almost-70-of-neighbour-disputes-heard-by-tribunalsinvolve-excessive-noise (accessed 19 August 2018). 